кадров) : дисс. ... канд. пед. наук : 13.00 .02 / Шмис Тигран Гамлетович. - Красноярск, 2004. - $161 \mathrm{c}$.

19. Ясвин В. А.Образовательная среда: от моделирования к проектированию / Витольд Альбертович Ясвин. - М. : Смысл, 2001. - 365 с.

Стаття надійшла до редакції 01.06.2012 p.

УДК 378.147.111

T. С. Фіногеєва, викладач,

Стахановський навчально-науковий інститут гірничих та освітніх технологій Украӥнської інженерно-педагогічної академії

\title{
САМОСТІЙНА РОБОТА В НАВЧАЛЬНОМУ ПРОЦЕСІ ВИЩИХ ІНЖЕНЕРНО-ПЕДАГОГІЧНИХ НАВЧАЛЬНИХ ЗАКЛАДІВ: СУЧАСНИЙ СТАН ТА ПЕРСПЕКТИВИ
}

Фіногєєва Т. С. Самостійна робота в навчальному процесі вищих інженерно-педагогічних навчальних закладів: сучасний стан та перспективи.

У статті на основі дослідження сучасних педагогічних праџь здійснено аналіз системи самостійної роботи майбутніх інженерів-педагогів, ї̈ дидактичних умов та передумов. Автор пропонуе шиляхи удосконалення самостійної роботи студентів інженерно-педагогічних навчальних закладів.

Ключові слова: самостійна робота, самостійність, інженер-педагог, дидактичні умови, дидактичні передумови.

Финогеева T. Е. Самостоятельная работа в учебном прочессе высших инженернопедагогических учебных заведений: современное состояние и перспективы.

В статье на основе исследований современных педагогических трудов осуществлен анализ системы самостоятельной работы будущих инженеров-педагогов, ее дидактических условий и предпосылок. Автор предлагает пути усовершенствования самостоятельной работь студентов инженерно-педагогических учебных заведений.

Ключевые слова: самостоятельная работа, самостоятельность, инженер-педагог, дидактические условия, дидактические предпосылки.

Finohyeyeva T. E. Independent work in the educational process of higher engineering and teacher training institutions: current status and perspectives.

In this article on the basis of studies of modern pedagogical work carried out an analysis of the system of independent work of future teacher-engineers, its teaching conditions and prerequisites. The author offers ways to improve students' independent work of engineering and teacher training institutions.

Key words: independent work, self-reliance, teacher-engineer, teaching conditions, teaching prerequisites.

Самостійна робота студентів посідає визначальне місце у процесі навчання майбутніх інженерів-педагогів. Переорієнтація навчального процесу більшою мірою на самостійність в отриманні знань та формування умінь i навичок зумовлена тим, що нова парадигма освіти відносить самостійну навчальну роботу до однієї з основних форм організації процесу навчання у вищій школі, здатної забезпечити самореалізацію та саморозвиток майбутніх фахівців. Особливості самостійної роботи в умовах вищої інженернопедагогічної школи розглянуто у працях Л. Горбатюк [2], Н. Зоніної [3], В. Кислякова [4], О. Коваленко [5], Л. Назарової [9], Г. Плієва [10] та інших. 
Водночас аналіз стану організації самостійної роботи студентів дозволив виявити низку педагогічних проблем. У більшості випадків у навчальному процесі ВНЗ самостійна робота не має диференційованого й індивідуалізованого характеру залежно від специфіки дисципліни, навчального матеріалу та особистісних якостей студентів. Нині в сучасних педагогічних роботах практично відсутні чіткі методики з формування вмінь і навичок самостійної роботи, визначення реального бюджету часу на основі пошуку оптимального поєднання навчальної й самостійної діяльності студентів під час навчання у ВНЗ.

Мета статті - визначення місця та ролі самостійної роботи студентів в навчальному процесі вищих інженерно-педагогічних навчальних закладів.

Задля 3'ясування місця самостійної роботи у процесі навчання майбутніх інженерів-педагогів нами було здійснено аналіз навчальних планів підготовки за освітньо-кваліфікаційним рівнем бакалавр Української інженерно-педагогічної академії i визначено співвідношення частки самостійної роботи до аудиторних занять. За результатами порівняння було складено діаграму (див. рис. 1), яка наочно доводить, що самостійна робота в навчальному процесі вищих інженерно-педагогічних навчальних закладів передбачає використання близько половини загального обсягу навчального часу. Таке становище вимагає особливого ставлення до цього виду навчальної діяльності з боку викладачів та студентів, розроблення нових форм iї організації й контролю.

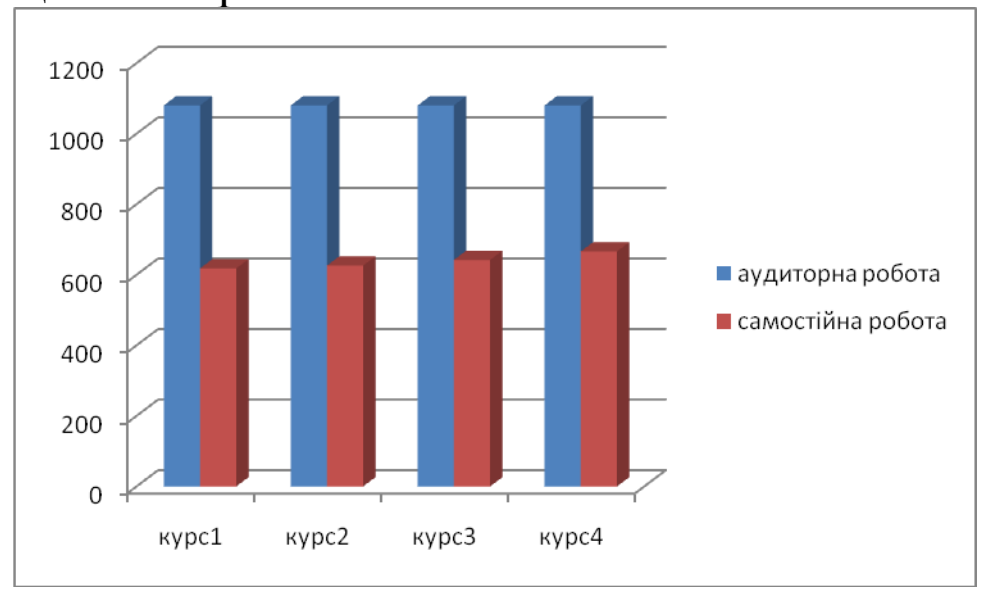

Рис. 1. Співвідношення часу на аудиторну й самостійну роботу студентів інженерно-педагогічних спеціальностей

Отже, можна зробити висновок, що самостійна робота посідає важливе місце у процесі навчання майбутніх інженерів-педагогів. Ми згодні 3 дослідниками, які вважають, що задля підвищення ефективності навчання необхідно створювати систему самостійної роботи, результатом якої $\epsilon$ формування умінь і навичок самостійної навчальної діяльності, здатності до самонавчання, саморозвитку й самоосвіти [6;7].

Ми вважаємо, що створювати систему самостійної роботи студентів бажано 3 першого курсу навчання у вищому інженерно-педагогічному навчальному закладі, оскільки для переважної кількості студентів- 
першокурсників майже невідомі форми, методи і засоби навчання саме у вищій школі, у тому числі й самостійної роботи як провідної форми організації самостійної навчальної діяльності. Вони змушені засвоювати нові елементи технології й культури розумової праці. На початковому етапі організації самостійної роботи студентів необхідною $є$ безпосередня участь викладача в навчальній діяльності студента задля того, щоб формування вмінь і навичок самостійної роботи відбувалось на свідомій основі [7].

На основі досліджень О. Малихіна ми пропонуємо під час створення ефективної системи самостійної роботи студентів у вищому інженернопедагогічному навчальному закладі дотримуватися низки вимог [7]:

- єдності цілей усіх видів навчальної діяльності;

- комплексного забезпечення самостійної роботи студентів: організаційного, навчально-методичного, інформаційно-технічного;

- педагогічного i практичного спрямування самостійної роботи студентів;

- варіативності, творчого i професійно-орієнтованого характеру дидактико-пізнавальних завдань для самостійного виконання з урахуванням індивідуально-психологічних особливостей студентів;

- управління самостійною роботою студентів із поетапним контролем результатів, залучення самих студентів до процесу управління.

В. Король уважає, що важливим завданням при створенні системи самостійної роботи студентів $\epsilon$, по-перше, навчити їх учитися i, по-друге, ознайомити з психофізіологічними основами розумової праці, технікою іiі наукової організації, що здійснюється цілеспрямовано у вищому навчальному закладі протягом вивчення курсу «Вступ до фаху», а також у процесі управління індивідуальною роботою [6].

На нашу думку, метою самостійної роботи студентів інженернопедагогічних спеціальностей $\epsilon$ : систематизація i закріплення отриманих теоретичних знань і практичних умінь; поглиблення й розширення теоретичних знань; формування умінь використовувати нормативну, довідкову та спеціальну літературу; розвиток пізнавальних здібностей та активності, творчої ініціативи, самостійності, відповідальності та організованості; формування самостійності мислення, здатності до саморозвитку, самовдосконалення та самореалізації; розвиток дослідницьких умінь.

Розглянемо функції самостійної роботи студентів вищих навчальних закладів.

В. Король уважає, що самостійна роботи виконує такі функції [6]: навчальну; пізнавальну; коригувальну; стимулювальну; виховну; розвивальну.

I. Мельник обгрунтовує такі дидактичні функції самостійної роботи студентів [8]: закріплення знань та вмінь, отриманих на лекціях; розширення й поглиблення навчального матеріалу; формування вмінь і навичок самостійного пошуку інформації, iii аналіз, узагальнення; розвиток самостійного мислення шляхом виконання індивідуальних завдань поза рамками навчальної програми; виконання індивідуальних спостережень, дослідів; укладання й підготовка навчальних посібників, дидактичного матеріалу. 
На основі зазначеного вище пропонуємо такі основні функції самостійної роботи студентів у вищих інженерно-педагогічних навчальних закладах:

- пізнавальна функція, пов'язана із засвоєнням систематизованих знань відповідно до освітньо-професійної програми підготовки майбутнього інженера-педагога;

- планувальна функція: формування вмінь і навичок, самостійного їх оновлення і творчого застосування;

- прогностична функція, яка полягає в повсякчасному передбаченні й оцінюванні студентами як можливого результату, так і власне виконання завдання в майбутній інженерно-педагогічній діяльності;

- коригувальна функція, яка полягає в потребі своєчасної корекції своєї діяльності;

- виховна функція, пов'язана з формуванням самостійності як риси характеру майбутнього інженера-педагога;

- функція персоналізації, яка надає змогу максимально наблизити (уподібнити) навчальну діяльність до майбутньої професії через систему пізнавальних завдань із професійно-орієнтованих дисциплін нормативного та варіативного циклів.

Здійснимо аналіз передумов та умов ефективної самостійної роботи студентів. За характером впливу на самостійну роботу доцільно розділити передумови на дві групи: зовнішні (професіоналізм діяльності викладача, цілепокладання, організація самостійної роботи студентів, відбір змісту самостійної роботи студентів, мотивацію (зовнішню і внутрішню) та внутрішні (індивідуальні). Самостійна робота визначається єдністю зовнішніх i внутрішніх умов. До внутрішніх дидактичних передумов самостійної роботи студентів можна віднести: рівень попередніх знань, сформованість навичок самостійної роботи.

О. Якубовська, розглядаючи самостійну роботу в контексті особистісно орієнтованого навчання, визначила дидактичні вимоги, яким має відповідати особистісно орієнтована самостійна робота [12]:

- навчальний матеріал має передбачати виявлення змісту суб'єктного досвіду студента, включаючи досвід його попереднього навчання;

- самостійна робота із засвоєння знань має бути спрямованою на постійне перетворення набутого суб'єктного досвіду кожного студента;

- у процесі самостійної роботи необхідним $є$ постійне узгодження суб'єктного досвіду студентів з науковим змістом набутих знань;

- необхідне активне стимулювання студентів до самостійної освітньої діяльності, зміст і форми якої мають забезпечувати можливість самоосвіти, саморозвитку, самовираження в процесі оволодіння знаннями;

- конструювання навчального матеріалу, що надає змогу студентові визначати його зміст, обирати вид та форму під час самостійного виконання завдань тощо;

- виявлення й оцінка способів навчальної роботи, якими студент користується самостійно; 
- забезпечення контролю й оцінки не тільки результату, а й головним чином процесу самоосвіти студента; самостійна робота забезпечує рефлексію, оцінку учіння як суб'єктної діяльності студента.

О. Погрібна головними педагогічними умовами ефективності самостійної роботи студентів називає такі [11, с. 126]: уведення модульнорейтингової системи навчання; ієрархія рівнів управління самостійною роботою студентів у вищому навчальному закладі; урахування низького рівня самостійності студентів-першокурсників; розроблення викладачем i надання студентам зразків виконання складних завдань; дотримання психогігієнічних норм розумової праці; забезпечення студентів навчальнометодичними матеріалами 3 дисципліни; визначення викладачем чіткого змісту і методів виконання завдань для самостійної роботи студентів; проведення консультативних та індивідуальних занять; активізація позитивної мотивації навчання; забезпечення належного і своєчасного контролю з боку викладача за виконанням завдань для самостійної роботи; надання студентам можливості підвищити рейтинг за умов недостатньої кількості балів шляхом виконання додаткових (вибіркових) завдань; створення позитивного мікроклімату на заняттях, атмосфера співпраці між студентами і викладачем; диференційований підхід до вибору методів навчання й контролю знань; оптимальне поєднання різних видів самостійної діяльності студентів; упровадження нових форм організації самостійної роботи студентів; нетрадиційні підходи до проведення занять.

О. Біда пропонує такі умови ефективної самостійної роботи в умовах вищого навчального закладу [1]: забезпечення правильного сполучення обсягу аудиторної і самостійної роботи; методично правильна організація роботи студента в аудиторії і поза нею; забезпечення студента необхідними методичними матеріалами задля перетворення процесу самостійної роботи на процес творчий; контроль за організацією і процесом самостійної роботи, що заохочує студента якісно її виконувати.

На наш погляд, перераховані вище умови не враховують специфіки навчання в інженерно-педагогічному ВНЗ (об'єднання професійнопедагогічної та професійно-інженерної складових). Ми вважаємо, що ефективність самостійної навчальної роботи студентів інженернопедагогічних спеціальностей залежить від дотримання таких дидактичних умов: оптимальне поєднання матеріалу, що пропонується викладачем, iз самостійною роботою студентів; урахування індивідуально-психологічних особливостей, реальних умінь і навичок навчальної діяльності студентів та вимоги професійної спрямованості під час складання варіативної дидактичної системи пізнавальних завдань для самостійної роботи; керівництво самостійною роботою на основі методичних інструкцій і дидактичних матеріалів; урахування індивідуальних особливостей студентів під час організації змісту навчальної роботи; використання пізнавальних завдань проблемного характеру; забезпечення якісного і всебічного контролю за виконанням системи пізнавальних завдань. За дотримання таких умов зросте 
якість оволодіння студентами змістом освіти, підвищиться інтенсивність їхньої навчальної діяльності, а самостійна робота студентів буде характеризуватися високим рівнем пізнавальної активності й самостійності.

Відбір і структурування змісту для самостійної роботи відбувається за такими принципами: модульності; системності; міждисциплінарності й інтеграції; індивідуалізації й диференціації; креативності для формування у студентів навичок розв'язання дидактико-пізнавальних завдань на репродуктивному, реконструктивному та творчому рівнях складності; компенсаторності; багаторівневості, що передбачає забезпечення «поетапного» ускладнення змісту навчально-дослідницької діяльності шляхом скорочення або помноження завдань дослідження, звуження або розширення «інформаційного поля» дослідницьких завдань.

Ми вважаємо, що ефективність самостійної роботи студентів інженерно-педагогічних спеціальностей залежить від:

- якісного планування навчального процесу;

- наявності навчально-методичного комплексу дисципліни, до якого входять спеціально підготовлені навчально-методичні матеріали для самостійної роботи студентів;

- ефективних форм контролю й оцінювання результатів самостійної роботи студентів;

- диференціації пізнавальних завдань для самостійної роботи студентів;

- ефективних навчальних технологій, у яких самостійна робота студентів є невід'ємною складовою.

На основі викладеного вище можна виокремити такі шляхи вдосконалення самостійної роботи майбутніх інженерів-педагогів:

- забезпечення єдності освітньої, виховної і розвивальної функцій навчання;

- реалізація комплексу принципів навчання і принципів розвитку самостійної пізнавальної діяльності;

- забезпечення динамічності навчання, його спрямованості на розвиток активності розумової діяльності студентів;

- орієнтація студентів на систематичну самостійну пізнавальну діяльність і вдосконалення іï організації;

- розроблення й педагогічно-доцільне використання навчальнометодичного комплексу дисциплін, до якого входять спеціально підготовлені навчально-методичні матеріали для самостійної роботи студентів;

- використання системи психолого-педагогічних стимулів щодо активної самостійної пізнавальної діяльності студентів;

- використання максимальною мірою особистісно орієнтованих технологій навчання.

\section{Лiтература}

1.Біда О. А. Сучасні тенденції в організації самостійної роботи студентів ВНЗ [Електронний ресурс] / О. А. Біда, О. П. Савченко // е-журнал «Педагогічна наука: історія, 
теорія, практика, тенденції розвитку», 2010. - №2: - Режим доступу до статті: http://intellect-invest.org.ua/pedagog_editions_eagazine_pedagogical_science_vypuski_ n2_2010_st_14/

2.Горбатюк Л. В. Особливості організації самостійної роботи студентів інженернопедагогічних спеціальностей із застосуванням комп'ютерних технологій / Л. В. Горбатюк // Проблеми інженерно-педагогічної освіти. - Х., 2004. - Вип. 8. - С. 102-105.

3.Зонина Н. А. Формирование профессионально-педагогических умений студентов инженерно-педагогических специальностей в процессе педагогической практики : автореф. дис. на соиск. учен. степ. канд. пед. наук : спец. 13.00.08 «Теория и методика профессионального образования» / Н. А. Зонина. - М., 2000. - 21 с.

4.Кисляков В. В. Дидактические условия профессионально-педагогической направленности учебно-воспитательного процесса в педвузе (На материале спецдисциплин инженерно-педагогической подготовки) : автореф. дис. на соиск. учен. степ. канд. пед. наук : спец. 13.00.08 «Теория и методика профессионального образования» / В. В. Кисляков. - Волгоград, 2003. - 24 с.

5. Коваленко О. Е. Концепція професійно-педагогічної підготовки студентів інженернопедагогічних спеціальностей / О. Е. Коваленко, Н. О. Брюханова, О.О. Мельниченко // Проблеми інженерно-педагогічної освіти. - Х., 2005. - Вип. 10. - С. 7-20.

6.Король В. М. Управління самостійною та індивідуальною роботою студентів протягом навчання у ВНЗ / В. М. Король // Вісн. Черкаського університету: Пед. науки. Черкаси, 2008. - № 120. - С. 98-105.

7.Малихін О. В. Форми організації самостійної навчальної діяльності студентів вищих педагогічних навчальних закладів [Електронний ресурс] / О. В. Малихін. - Режим доступу до статті: http://intellect-invest.org.ua/pedagog_editions_e-agazine_pedagogical_ science_vypuski_n2_2010_st_14/.

8.Мельник I. М. Самостійна робота у професійній підготовці майбутнього вчителя початкових класів / I. М. Мельник, І. В. Мельник // Вісн. Черкаського університету: Пед. науки. - Черкаси, 2008. - № 126. - С. 103-108.

9.Назарова Л. И. Проектирование содержания и методики обучения студентов инженерно-педагогических специальностей основам педагогической инноватики : автореф. дис. на соиск. учен. степ. канд. пед. наук : спец. 13.00.08 «Теория и методика профессионального образования» / Л. И. Назарова. - М., 2000. - 24 с.

10. Плиев Г. А. Дидактические условия реализации принципа гуманитаризации учебно-воспитательного процесса в педагогическом вузе : (на материале инженернопедагогической подготовки) : автореф. дис. на соиск. учен. степ. канд. пед. наук : спец. 13.00.08 «Теория и методика профессионального образования» / Г. А. Плиев. - Волгоград, 2003. $-22 \mathrm{c}$.

11. Погрібна О. О. Педагогічні умови ефективної організації самостійної роботи студентів у ході вивчення курсу «Теорія масової комунікації» / О. О. Погрібна // Вісн. Черкаського університету: Пед. науки. - Черкаси, 2010. - № 176. - С. 122-127.

12. Якубовська О. М. Самостійна робота у контексті особисто-орієнтованого навчання / О.М.Якубовська // Організація самостійної роботи слухачів в умовах інформаційного суспільства : матеріали науково-методичної конференції 14 грудня 2001 p. - Одеса: ОРІДУ УАДУ, 2002. - С. 211-212.

Стаття надійшла до редакції 01.06.2012 p. 